UDC 330.3

JEL L25, H610, G340

DOI 10.31375/2226-1915-2021-1-29-43

\title{
ANALYSIS OF THE FACTORS THAT INFLUENCE PERFORMANCE IN THE IMPLEMENTATION OF REGIONAL BUDGETS AS AN EFFORT TO ACHIEVE A PROPER GOVERNMENT IN PAPUA
}

\author{
Ramasoyan A.L. \\ Lecturer \\ Corresponding email: ramasoyan.all@gmail.com \\ Orcid ID: https://orcid.org/0000-0002-2443-5354 \\ Arung Lamba' \\ Professor of Economics \\ Kurniawan Patma, Rudiawie Larasati \\ Faculty of Economy and Business \\ Universitas Cenderawasih \\ Kamp Wolker street, Kambolker Perumnas III, Yabansai, \\ Heram, Jayapura city, Papua 99224, Indonesia
}

\begin{abstract}
The purpose of this research is to analyze and calculate the magnitude on the influence of: 1) Human resources for the accountability of regional budget implementation; 2) accountability technology of regional budget execution; 3) performance transparancy of regional budget execution; 4) Public participation and Legislative political support for performance of regional budget implementation; 5) Accountability of regional budget implementation to the performance of regional budget execution in Papua. The method that used is qualitative and quantitative analysis within the descriptive approach and SEM (Structural Equation Model) approach. Based on this analysis it shows that: 1) There is a positive and significant influence of human resources on the regional accountability of budget implementation, however it is not significant; 2) There is a positive effect of technology on the accountability of regional budget execution, however it is not significant; 3) There is a positive and significant influence from the condition of trans-parency on the accountability of regional budgets implementation; 4) There is a positive but insignificant influence from the conditions of public participation on the accountability of regional budget implementation and there is a positive and significant influence on legislative political support of the accountability of regional budget implementation; 5) There is a positive and significant influence on the condition of accountability of regional budgets implementation on the performance of regional budget execution in Papua Province. It can be concluded that several factors can influence the Performance of Regional Budgets Implementation as an Effort to Achieve Good Government in Papua.
\end{abstract}

Keywords: Performance, Budget and Accountability.

(C) Ramasoyan A.L., Arung Lamba', Kurniawan Patma, Rudiawie Larasati, 2021 
УДК 330.3

JEL L25, H610, G340

DOI 10.31375/2226-1915-2021-1-29-43

\section{АНАЛІЗ ФАКТОРІВ, ЩО ВПЛИВАЮТЬ \\ НА ЕФЕКТИВНІСТЬ ВИКОНАННЯ РЕГІОНАЛЬНИХ БЮДЖЕТІВ \\ ЯК ФАКТОР НАЛЕЖНОГО ВРЯДУВАННЯ}

Рамасоян А.Л.

email: ramasoyan.all@gmail.com

Orcid ID: https://orcid.org/0000-0002-2443-5354

Арунг Ламба

професор економіки

Курніаван Патмен, Рудіаві Ларасаті

Факультет економіки і бізнесу

Університет Чендравасіх

Камболкер-Перумнас III, Ябансай, херам,

місто Джаяпура, Папуа 99224, Індонезія

Анотація. Мета иього дослідження проаналізувати та розрахувати величину впливу. 1) людських ресурсів на контрольованість виконання регіонального бюджету; 2) технології підзвітності виконання регіонального бюджету 3) прозорості результатів виконання регіонального бюджету; 4) державної участі та законодавчої політичної підтримки виконання регіонального бюджету; 5) підзвітність виконання регіонального бюджету. Методом, що використовується, $\epsilon$ якісний та кількісний аналіз в рамках описового підходу та підходу SEM (Mодель структурного рівняння). На основі иього аналізу можна зробити наступні висновки: 1) $\epsilon$ позитивний та значний вплив людських ресурсів на регіональну підзвітність виконання бюджету; 2) існує позитивний вплив технологіï на підзвітність виконання регіонального бюджету, але він не є суттєвим; 3) існує позитивний $i$ значний вплив від умов прозорості на підзвітність виконання регіональних бюджетів; 4) є позитивний, але незначний вплив від умов участі громадськості на підзвітність виконання регіонального бюджету, також існує позитивний та значний вплив на законодавчу політичну підтримку підзвітності виконання регіонального бюджету; 5) позитивний та значний вплив на стан підзвіт-ності виконання регіональних бюджетів та на результати виконання регіонального бюджету в провіниії Папуа. Можна зробити висновок, щчо декілька факторів можуть впливати на ефективність виконання регіональних бюджетів $і$ стати інструментом досягнення належного врядування в Папуа.

Ключові слова: ефективність, бюджет підзвітність
УДК 330.3

JEL L25, H610, G340

DOI 10.31375/2226-1915-2021-1-29-43

\section{АНАЛИЗ ФАКТОРОВ, ВЛИЯЮЩИХ НА ВЫПОЛНЕНИЕ РЕГИОНАЛЬНЫХ БЮДЖЕТОВ КАК УСИЛИЕ \\ ПО ДОСТИЖЕНИЮ НАДЛЕЖАЩЕГО ПРАВЛЕНИЯ В ПАПУА}

Рамасоян А.Л.

Арунг Ламба

профессор экономики

Курниаван Патма, Рудиави Ларасати

Факультет Экономики и бизнеса

Университет Чендравасих

Камболкер-Перумнас III, Ябансай, Херам,

город Джаяпура, Папуа 99224, Индонезия

Аннотация. Цель этого исследования проанализировать и рассчитать величину влияния: 1) человеческих ресурсов на контролируемость выполнения регионального бюджета; 2) технологии подотчетности выполнения регионального бюджета; 3) прозрачности результатов выполнения регионального бюджета; 4) государственного участия и законодательной политической поддержки выполнения регионального бюджета; 5) подотчетность выполнения регионального бюджета. Методом, который используется, является качественный и количественный анализ в рамках описательного подхода и подхода SEM (Модель структурного уравнения). На основе этого анализа можно сделать следуюшие выводы: 1) существует положительноое и значительное влияние человеческих ресурсов на региональную подотчетность выполнения бюджета; 2) существует положительное влияние технологии на подотчетность выполнения регионального бюджета, но оно не является существенным; 3) существует положительное и значительное влияние от условий прозрачности на подотчетность выполнения региональных бюджетов; 4) существует положительное, но незначительное влияние от условий участия общественности на подотчетность выполнения регионального бюджета, также существует положительное и значительное влияние на законодательную политическую поддержку подотчетности выполнения регионального бюджета; 5) положительное и значительное влияние на состояние подотчетности выполнения региональных бюджетов и результатов выполнения регионального бюджета в провиниии Папуа. Можно сделать вывод, что несколько факторов могут влиять на эффективность выполнения региональных бюджетов и стать инструментом достижения надлежащего правления в Папуа.

Ключевые слова: производительность, бюджет и подотчетность. 
Problem statement. The economic crisis experienced by most countries in 1997 led to a decline in economic activity in many countries, including Indonesia; it had an impact on the increase in unemployment, poverty and other social problems, and triggered various forms of demonstrations in some areas (1). It was dissatisfaction with the government at that time.

In the regional financial management system, the implementation is carried out with the reference of Law Number 22/1999 on Local Government and Law Number 25/1999 on Financial Ba-lance among the Central and Local Go-vernments has many weaknesses; because it tends to be centralized as a result of many regulatory principles set which controlled by central government. Local budgets are still fixed, thus, it will not able to accommodate people's aspirations. As a management instrument, regional budgets are still not transparent, not accountable; do not reflect the spirit of decentralization and democratization, resulting in low financial management performance in the regions. As management instrument, regional budgets still not transparent, not accountable, and not reflect the spirit of decentralization and democratization yet, it has a result in low financial management performance of regions (2). As a result, the budget becomes a source of waste which only causes the benefits for certain parties. At the same time, year after year, the state and regional budgets of various regions have seen amazing growth.

Loho (2017) pointed out that some national evidence on regional financial mismanagement can be seen from the review of the 2012 regional budget calculations for ten provinces in eastern Indonesia, which shows that there is no «opinion» in the calculation of the provincial regional budget, Twenty opinions received «reasonable exceptions» (WDP), and eight opinions received «mandatory exceptions».

From the above point of view, it can be seen that the government needs to have regional financial management tools or systems related to demand and regional autonomy (4). And clear guidelines for the management of regional finance through regional regulations, aiming to provide flexibility to determine the financial management regulations of regional governments.

Related to the implementation of regional autonomy and good governance, some of the abovementioned basic principles of public financial management often arouse public judgments or questions on the following issues, such as: the human resources owned by Papua Province, the transparency of the existing budget, the availability of technology, the regional budget participation, political support and accountability.

This research aims to determine the effect of human resources on the accountability of local budget implementation, the influence of technology toward the accountability for the of regional budgets implementation, The impact of transparency on regional budget implementation performance, the impact of people's participation on regional budget implementation, the impact of legislative political support on regional budget implementation, and the impact of accountability on regional budget implementation A report on 
Papua's regional budget implementation. publications.

Review of the last research and

1. The Concept of Autonomy and Decentralization. Yani (2012), stated that Autonomy comes from the greek word, auto means independence and nomous means law, whereas in Dutch literature, autonomy means «selfgovernment» (Zelfregering). The term «Decentralization» defined as the delegation of authority from the center to regions. Moreover, it is said that; in the government system, there are two forms of relationship between the central and regional governments, such as centralization and decentralization. Centralization means that under the power of the central government, every matter, responsibility, function and authority in government management is carried out in a deconcentrated implementation. At the same time, decentralization means that every function, task and authority performed by the government is completely delegated to the region.

In the promulgation of Law № 33/2004, it brought about fundamental changes in financial relations and adjustments in regional budget management, paving the way for the implementation of public sector reforms. The result of the implementation of the law is the power to the principle of decentralization (6). Therefore, in the context of implementing regional autonomy, each region of the government is delegated to each region. Basically, it becomes the full power and responsibility of the regional government to implement and resolve issues including regional responsebilities and interest concerns.
2. The Concet of Government Expenditure. Government expenditure is a budget that issued by central government which allocated in public sector such as education, health and infrastructure.

According to Suparmoko (2014); government expenditure can be assessed from various aspects and it can be divided into:

a. Expenditure is an investment that provide the future economic resilience;

b. Expenditure immediately provides welfare and joy to the society;

c. Expenditure is a savings future expenses;

d. Provide more job opportunities and wider distribution of purchasing power.

3. Economic Growth Theory and Government Expenditure Budget.

The theory of stages economic growth from Rostow 1956 was developed by Musgrave in 1975 and connecting the stages of economic growth with the development of government expenditure budget, it distinguished the initial stage, intermediate stage, and advanced stage (8). It is said that; in early stages of economic development, the percentage of government investment to total investment is large, because at this stage, government should provide several infrastructures, such as: education, health, transportation infrastructure, and others. In the center stage of economic development, governmental investment required to increase the economic growth, however, the role of private investment is getting bigger. 
At a further economic level, economic development of government activities relocated from the provision of infrastructure to expenditures of social activities such as; Old-age pensions program, society health service programs and others.

4. Wagner's Law Concerning on the Development of Governmental
Activities. Rostow and Musgrave's theory above used as a basis by Wagner 1980 in his other theory of The development on government expenditure budget which referred as Wagner Law of Increased Government Activity (8), and this is indicated as Grand Theory of this research as what is stated in figure 1 below:

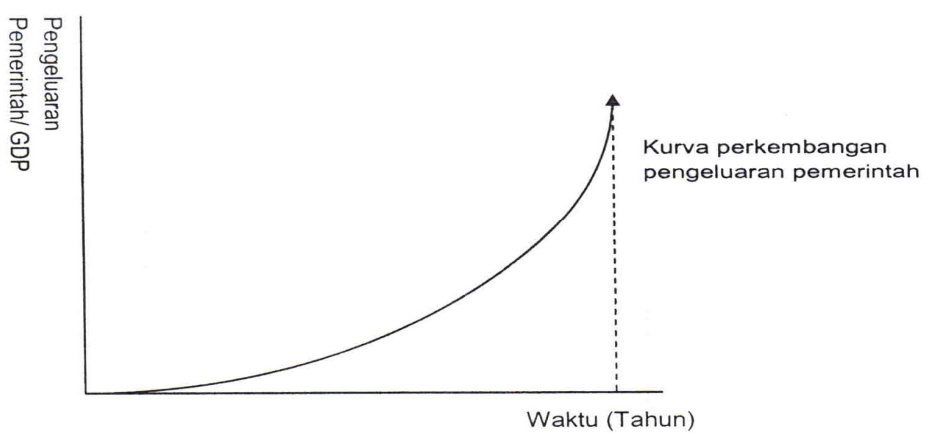

Source: (8)

Fig. 1. Wagner Law Curve

Based on Wagner's Law, it can be shown that the increase of government spending has an exponential form which is indicated by the development curve of government spending.

\section{Theory of Sources Regional}

Revenue. Within the enactment of Law Number 32/2004 concerningn on Regional Government and Law Number 33/2004, regarding Financial Balance between Central and Regional Government, regional government has the authority to carry out its activities and development and broader authority in obtain the sources of funding, whether from the region or from the State Revenue and Expenditure Budget. The sour-ces of regional financial revenues as mentioned above consist of:
a. Local generated revenue;
b. Balancing Fund;
c. Regional Loans.

6. Regional Government Budget Concept. Local Government Budget can be defined as an effort of: An activity plan represent in form of a plan for revenue and expenditure in monetary units of an area. Governmental Budget is a document that describes the financial condition of an organization which includes information of income, expenditure, activities and estimation of what regional organizations will be taken in the future.

According to Halim (2017), the main functions of local government's budget include the following: planning tools, control tools, fiscal policy tools, political tools, coordination and communication tools, performance appraisal tools, motivation tools, and public space tools. Furthermore, it can be said that; in Government Accounting Conceptual Framework, The budget within the go- 
vernment has an important function in accounting and financial report, for several reasons as below:

a. Government budget is a public policy statement;

b. Government budget is a fiscal target that describes the balance between spending, income and the expected financial;

c. Government budget becomes the basis for control which has legal consequences;

d. Government budget provides the basis for evaluating government performance;

e. The results of budget execution should be stated in government financial reports as government's responsibility to the public.

7. Regional Expenditure Management Principles. According to Halim (2017) and Arung Lamba' (2019), the principle management of regional spending consist of economical, efficiency, effectiveness, it has close relation to the law number 33/2004 regarding the Financial Balance of Central Government and Regional Government (article 66 paragraph 1) and Government Regulation Number 58/2005 concerning on Management and Accountability of Regional Financial (Article 4 paragraph 1) and the details inside the Ministry of Home Affairs regulation Number 13/ 2006 concerning on the Guidelines for Regional Financial Management include:
a. Accountability;
b. Transparency;
c. Participation;
d. Economy, Efficiency and Ef- fectiveness;
e. Human Resources and Tech- nology;
f. Political Support;
g. Formulation of Regional Go- vernment General Policies.

\section{CONCEPTUAL FRAMEWORK OF VARIABLES AND INDICATOR RELATIONSHIP}

The Figure of SEM Diagram, Path Relationship between Variables and Research Indicators (fig. 2).

Based on the figure above, it shows that: these latent variables will be observed by the following indicators as below:

1. Human Resources $\left(\mathrm{X}_{1}\right)$, will be measured through the following indicators; $\operatorname{ning}\left(\mathrm{X}_{11}\right)$;

a. Apparatur Education and trai-

b. Competence and skills $\left(\mathrm{X}_{12}\right)$;

c. Knowledge and understanding $\left(\mathrm{X}_{13}\right)$.
2. Technology $\left(\mathrm{X}_{2}\right)$; which will be measured through the following indicators as below;

a. The implementation of computerization $\left(\mathrm{X}_{21}\right)$;

b. The amount of equipment and infrastructure $\left(\mathrm{X}_{22}\right)$;

c. The type of equipment and infrastructure $\left(\mathrm{X}_{23}\right)$

$\mathrm{d}$. The condition of equipment and infrastructure $\left(\mathrm{X}_{24}\right)$.

3. Transparancy $\left(\mathrm{X}_{3}\right)$, will be measured through the following indicators as below; 


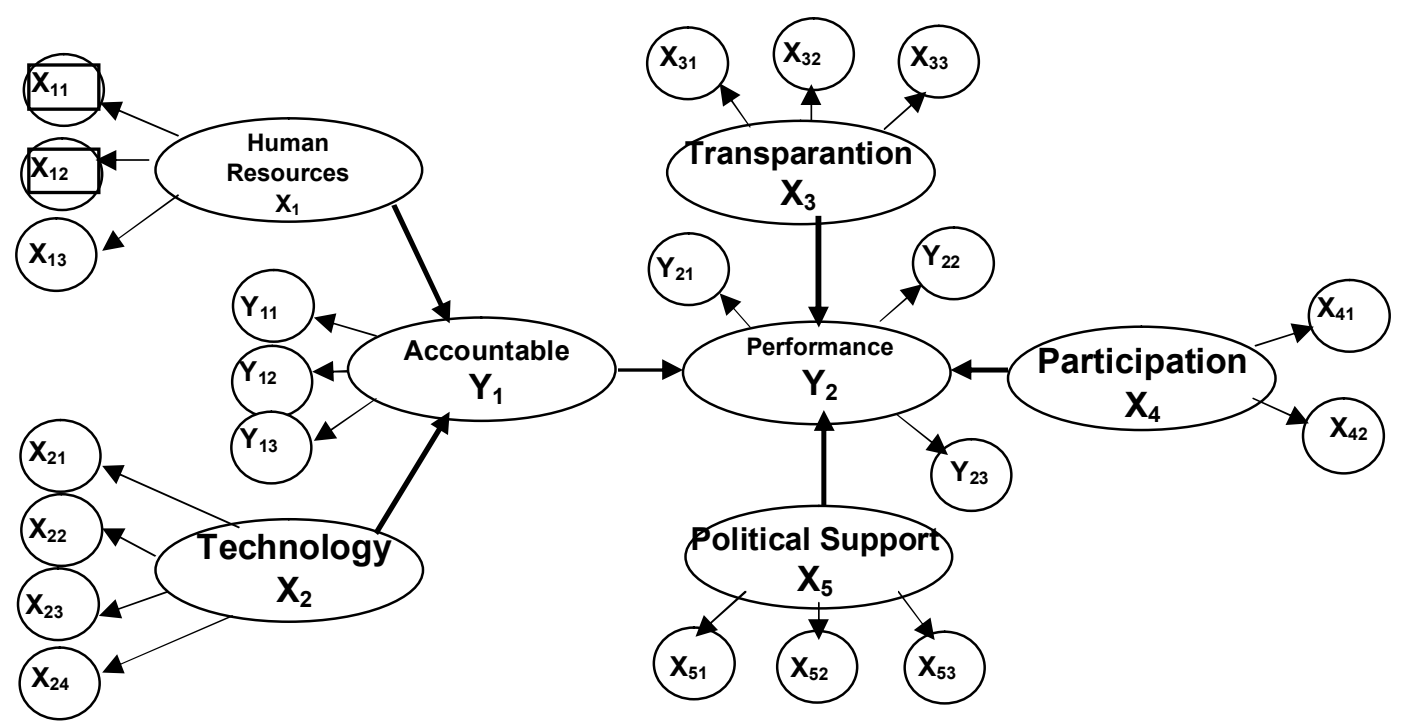

Fig. 2. SEM Diagram, Path Relationship between Variables and Research Indicators

Source: research conceptual framework, 2019

a. The ease of information access $\left(\mathrm{X}_{31}\right)$

b. The availability of media to complaints $\left(\mathrm{X}_{32}\right)$;

c. Dissemination of decisions through the mass media $\left(\mathrm{X}_{33}\right)$.

4. Participation $\left(\mathrm{X}_{4}\right)$, will be measured through the following indicators below;

a. People Aspirations in preparation of Regional Budget $\left(\mathrm{X}_{41}\right)$;

b. People involvement in the allocation of Regional funds $\left(\mathrm{X}_{42}\right)$.

5. Political Support $\left(\mathrm{X}_{5}\right)$ will be measured through the following indicators below;

a. Executive and legislative relations in field of supervision $\left(\mathrm{X}_{51}\right)$;

b. Executive and legislative relations in field of budget $\left(\mathrm{X}_{52}\right)$;

c. Executive and legislative relations in field of legislation $\left(\mathrm{X}_{53}\right)$.
6. Accountability $\left(\mathrm{Y}_{1}\right)$, will be measured through the following indicators below;

a. The accuracy of the Regional Budget implementation report to Regional Government $\left(\mathrm{Y}_{11}\right)$;

b. Regional financial accountability reports $\left(\mathrm{Y}_{12}\right)$;

c. Regional financial accountability report component $\left(\mathrm{Y}_{13}\right)$.

7. Regional Budget Implementation $\left(\mathrm{Y}_{2}\right)$ will be measured through the following indicators below;

a. Economical Implementation $\left(\mathrm{Y}_{21}\right)$;

b. The Efficiency of Implementation $\left(\mathrm{Y}_{22}\right)$;

c. The Effectivity of Implementation $\left(\mathrm{Y}_{23}\right)$. 


\section{RESEARCH METHODOLOGY}

1. Research Sample Area. This research was done in Papua. Administratively have 28 regencies and a city with Jayapura as the center of government with population of $3,469,753$ people in 2018. Within an excuse and consideration of bigger area and too many districts, the 3 sample of cities were determined as following below: 1) Jayawijaya Regency represents districts in mountainous areas; 2) Merauke district, besides representing districts in southern region, it also represents coastal areas; 3) Jayapura as the capital of Papua is also used as a barometer of the province condition.

2. Data Analysis Tools. The analyses used in this study are Qualitative and quantitative analysis using Structural Equation Model (SEM) analysis, within the following equation below:

$$
\begin{gathered}
\mathrm{Y}_{1}=\mathrm{b}_{1} \mathrm{X}_{1}+\mathrm{b}_{2} \mathrm{X}_{2}+\mathrm{e}_{1} \\
\mathrm{Y}_{2}=\mathrm{b}_{3} \mathrm{X}_{3}+\mathrm{b}_{4} \mathrm{X}_{4}+\mathrm{b}_{5} \mathrm{X}_{5}+\mathrm{b}_{6} \mathrm{Y}_{1}+\mathrm{e}_{2}
\end{gathered}
$$

(Solimun, 2002)

$\mathrm{Y}_{1}=$ Accountability

$\mathrm{Y}_{2}=$ Regional Budget Implementation

$\mathrm{X}_{1}=$ Human Resources

$\mathrm{X}_{2}=$ Technology

$\mathrm{X}_{3}=$ Transparancy

$\mathrm{X}_{4}=$ People Participation

$\mathrm{X}_{5}=$ Legislative Political Support

$\mathrm{b}_{1 \ldots 6}=$ endogen coefficient of influence of exogenous variables on endogenous variables

$$
\text { e1 to e21 }=\text { model error }
$$

\section{The basic material of research}

1. Result. The results of this study can be illustrated in figure of path of relationship between variables and research indicators within the SEM Overall
Structural Equation Model Test as following below - Fig.

\section{Discussion}

The Influence of Human Resources on Accountability of Local Budget Implementation. The analysis result regarding; the relationship between Human Resources and the Accountability of Local Budget Implementation indicated a coefficient path of $\mathrm{y}=0,01$, value, $\mathrm{CR}(0.10)<2,0$ and probability value $(0,92)>0,05$. It means that; Human Resources have positive but insignificant effect on the accountability of regional budgets implementation in Papua. Thus, the role of human resources in Papua cannot be considerate as the achievement of the accountability level in the implementation of regional budgets.

This finding is in line with the research result by Nara (2019) and Arung Lamba (2019), which state that; although local government has taken various policies as an effort to improve the quality of resources, such as involving personnel in education and training, both in structural and non-structural gaps, however sometimes the results are not visible, because it takes a long to adjust the activities.

Another fact that often occurs is the large number of personnel assigned to work unit that less relevant to the formal education they have. The theory obtained in formal education is not related to the field of duty.

This condition seems to occur to the whole country. nationally, local governments still experience many problems (12), include:

1. Insufficient financial resource; 


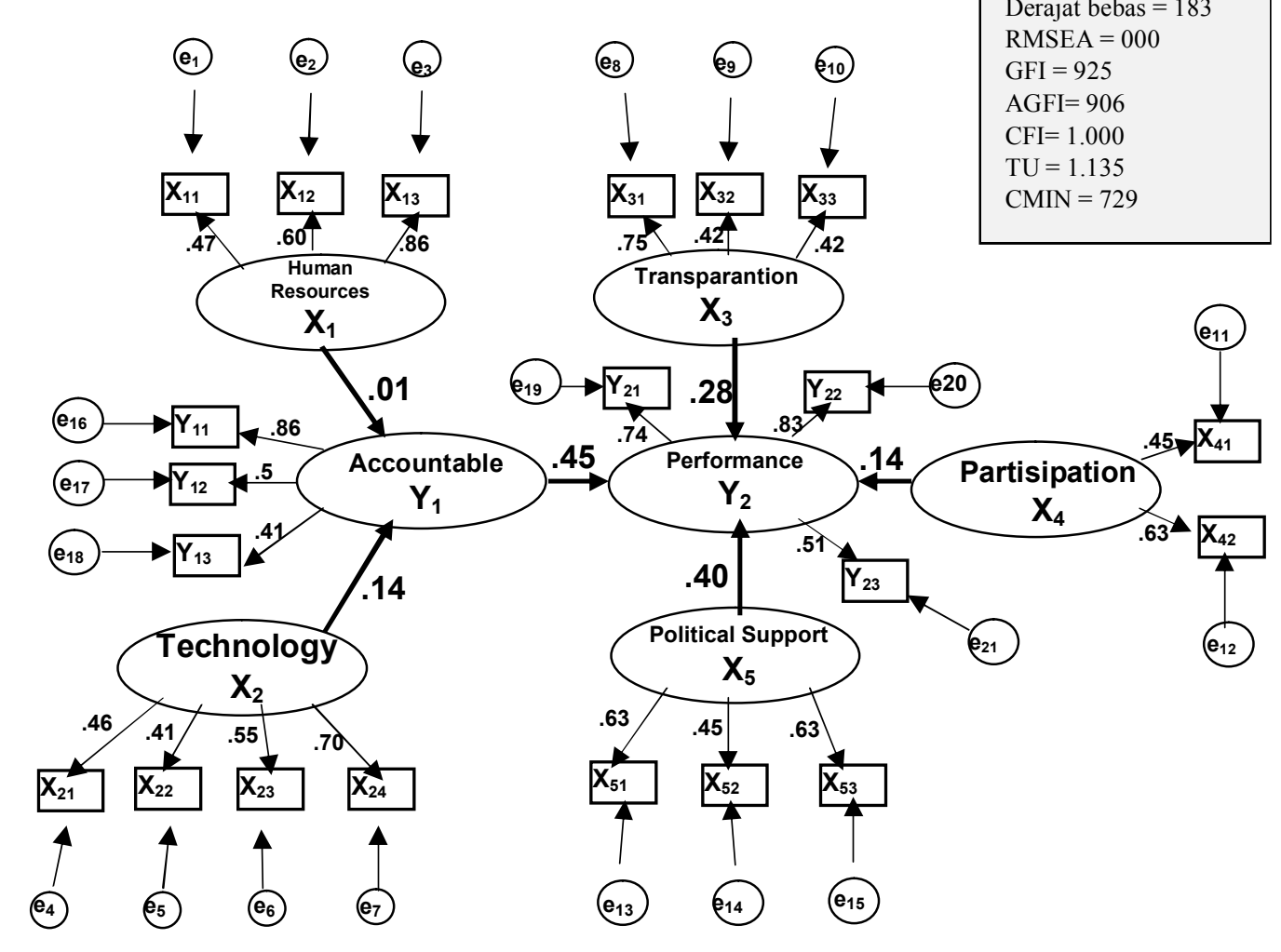

Fig. 3

Source: Conceptual Framework, 2019

2. The number of employees who have the skills and expertise is minimum;

3. Inadequate management control systems and procedures; low;

4. The employee productivity is

5. And others.

Mardiasmo (2010) stated that the development of local government apparatus resources should be carried out within the correct mechanism; therefore it will have implications for the creation of effective and efficient public services

which ultimately improve the performance of local governments.

The Effect of Technology on the Accountability of Local Budget Implementation

The analysis result of the relationship between technology and accountability of local budget implementation indicated that the path coefficient $\mathrm{y}=0,14$, $\mathrm{CR}$ value $(1,10)<2,0$ and probability $(0,27)>0,05$. It means that there is a positive but insignificant relationship between technology and accountability for the implementation of 
regional budgets. Within this finding, it can be said that the relationship between technology and accountability for the implementation of regional budgets, although positive, has not played many role in the realization of accountability for the implementation of regional budgets, which resulted in the creation of good regional budget execution performance.

This finding is related to the results of the study by Arung Lamba et al. (2019) which found that; although the influence of technology on the implementation of regional budgets is positive, however because the ability of human resources is still relatively low, the effect is low based on the results of research on the variable of technology, number, type, and condition of equipment and infrastructure used in regencies / cities in Papua Province, it can be explained that: the application of computerization has not been optimally done, this is because: besides the facilities and infrastructure used in form of computer devices and website networks to support a good work running, sometimes it cannot be used because of the network, and due to the low capacity of apparatus resources in utilizing technological advances, is the main obstacle that causes the use of technology (computerization) not yet optimal, and several people in region still unfamiliar with technology.

The Effect of Transparency on the Performance of Regional Budget Implementation. The Relationship between Transparency of Regional Budget Implementation and Performance which shows the number of path coefficient $\mathrm{y}=$ 0,28 , CR value $(2,51)>2,0$ and probability value $(0,0)<0,05$. From these values it can be interpreted that; there is a positive and significant influence between the transparency and the performance of regional budget implementation. These findings can be interpreted as: The better level of transparency in regional budget, the better performance of regional budget implementation will be. Thus, it can be said that; low level of transparency in the implementation of regional budgets, will be able to reduce the level of performance of regional budget implementation.

Based on the research data of transparency, it can be explained that; The elements that help to support the implementation of transparency are; there is convenience for the wider society to access an information regarding the implementation of Regional budget, there is a media as complaint mechanism that available if the society finds any indications of fraud in the implementation of regional budget, and the implementation is relative good within the dissemination of regulation through the mass media in several area.

Even though the presented transparency indicators above have become well implemented, However, one important factor that needs to be underlined from respondents' answers regarding the transparency is that publicly accessible facilities are difficult for most layers of society, especially those who live in rural areas, for example the access of internet, bulletins, and others.

The results of this research are related to the Irtanto's research in Halim, Abdul, (2017) from this research results, it can be concluded that; among 300 people who filled out the questionnaire, $56,4 \%$ of them answered that the 
indonesian radio media tend to have never been the target.

The Influence of Participation on the Performance of Regional Budget Implementation. The Analysis of relationship between the Participation variable and the Regional Budget Implementation Performance, indicated that the path coefficient value $\mathrm{y}=0,14$, the CR value $(0,98 \mathrm{~s})<2,0$ and the probability value $(0,33)>0,05$. These values can be interpreted as; there is a positive but insignificant influence between people participation and the performance of regional budget implementation.

Based on the finding above, it can be said that; the relationship between participation and regional budget implementation performance, positive, but insignificant in the realization of an economical, efficient and effective regional budget implementation. These findings support the research results of Riyanto and Ryan (2007), which state that; the effect of participation on performance of budget execution, positive but has not played a significant role in the realization on the implementation of regional budgets. However, he does not agree with the opinion of Tintri (2002) which states that; Participation in budgeting does not have a direct effect on managerial performance.

The conditions in field show that; the process of collecting aspirations which involve the preparation and allocation of the regional funds in various districts in Papua province has not been going well, because it has not involved any participation of society. Whereas people aspirations is a forum that accommodates the responses and opinions of many people, especially those related to the requirements of basic needs, and this is important because it is a standard of control for government to observe in what extent the government is serious about people aspirations. As many people pointed out, although the results of people aspirations through discussion, sometimes rarely forwarded to higher level of direction. The Lack of society involvement happens due to the lack of socialization, while socialization considered as important because local government should receive every public support.

The results of this study are consistent with those of Halim (2017); the society's view on fiscal decentralization is that $76,3 \%$ of the 300 respondents answered that they have never accepted the socialization of any political party, and Only 23,7 \% of the respondents believed that they had accepted socialization, and indicated that related institutions, social institutions, and other institutions were not helpful to the development of social politics.

The results of this study indicate that; There were $68,33 \%$ of society has not been involved in the public discussion regarding the regional budget, and $31,67 \%$ of respondents answered that they were involved in form of a Public Discussion regarding the development plan, the number of percentage indicated that; the society has not been enough chance to be involved in public discussion regarding the national budget. The aspirations of society should be the authority and task of district assembly, have not been effective. The mechanism for asking and listening to the board and public hearing has not been carried out optimally. The mechanism of asking and listening to the public hearing has not been optimally carried out. The District 
assembly should be proactive in carrying out the public aspirations and at the beginning of fiscal year; the related assembly should be able to formulate the direction and general policy of the APBD which then agreed with Regional Government. The process of collecting social aspirations has been implemented by the executive, both through formal mechanisms such and informal mechanism (interactive communication / dialogue with community leaders and nongovernmental organizations). Other obstacles that arise are regarding the results of discussion that included in Regional budget.

The Effect of Political Support on the Accountability of Local Budget Implementation. The results of the analysis on the relationship between Political Support variable and Regional Budget Implementation Performance, indicated that path coefficient of $\mathrm{y}=$ $0,40, \mathrm{CR}$ value $(3,31)>2,0$ and probability value $(0,00)<0,05$, which means that legislative political support has positive and significant effect on the performance of regional budget implementation.

Based on the findings, it can be interpreted that; the better legislative political support for the implementation of regional budgets in Papua, the higher performance of budget execution and vice versa, the lower the legislative political support in implementing regional budgets, the lower the performance of budget execution.

The results of this research did not support previous research from Arung Lamba (2010), which noted that several cases of unharmonious relations between legislature and the executive in several districts in Indonesia, although it cannot be denied that in several district assembly in Indonesia of 1999-2004 has incised legal violations regarding the history of Indonesia's district assembly, especially related to the case of corruption on regional budget, the extortion of several regional heads who carry out Accountability reports at the end of their term of office extortion on several regional heads who report on accountability at the end of their term. However, as far as the authors know, similar cases in districts assembly of Papua have never been proven that their involvement in their status is legally regulated. The political atmosphere in form of ethical relation between legislature and executive is an indicator of good political support for legislature of the executives in Papua to obtain the optimal performance.

From those three indicators that form the accountability variables, it can be concluded that; the important relationship between variable political support and regional budget execution performance mainly due to the good relationship between the executive branch and legislature in field of supervision and legislative environment.

The Impact of Budget Execution Responsibility System on Budget Execution Performance. The analysis results of the relationship between accountability variables and regional budget execution performance indicated that; Path coefficient $\beta=0,45, \mathrm{CR}$ value $(3,39)>2,0$, pro-bability value $(0,00)$ $<0,05$. It means that there is a positive and significant impact between the budget execution accoun-tability system and the regional budget execution performance. 
These findings can be explained that: the higher level of accountability in Papua regarding the implementation of regional budget, the better performance level of regional budget implementation, and vice versa. Therefore, this study draws the following conclusions: the relationship between accountability and budget execution performance in Papua is not only solid, but also indicated the important of accountability system to achieve economic, efficient and effective regional budget implementation

Based on the further value of each indicator load factor, it find that those three indicators constitute the accountability variables, it can be concluded that: The important relationship between accountability variables and regional budget implementation performance happen due to the implementation of Regional budget reports to District assembly (load factor 0,86 ). The next indicator which determines the significance of accountability variable is the form of report and the timing of accountability from the regional financial management official and the components of regional financial accountability report (loading factors are 0,51 and 0,41 , respectively).

This conclusion is strengthen by the answers received by respondents which all respondents stated that regional financial accountability is conducted by Regional Financial Accounting Standards, Furthermore, $86,11 \%$ of respondents said that the regional financial management staff compiled a regular financial responsibility report that was submitted every two months, and the remaining $13,89 \%$ of respondents said that they did not know regarding the report. In the regional budget implemen- tation routine report submitted to the regional council, $36,11 \%$ of the respondents answered that the report was submitted at the end of the year; $33,33 \%$ of the respondents answered that the report was submitted three months ago. After the end of the reporting period, the remaining 30,56 \% said they did not know. Several people suspect that the interviewee's answer is biased due to the fact that the interviewees are different in various fields/work departments, thus, the understanding of implementation on financial reports is relative insufficient, especially the main responsibility is not outside the financial department of respondents.

\section{CONCLUSION AND UGGESTION}

\section{Conclusion}

a. There is a positive but insignificant influence on human resources as measured by education and training indicators on the accountability of regional budget implementation. It means that human resources have not played an important role in Papua responsibility system for implementing regional budget.

b. There is a positive but insignificant effect of technology on the accountability of regional budget execution but it has not played many roles in the realization of accountability for the implementation of regional budgets in Papua.

c. There is a positive and significant influence from the condition of transparency on the accountability of regional budget implementation; it means that the transparency of regional budgets in Papua Province has played a role in achieving budget execution performance. 
d. There is no significant effect of public participation on the accountability of regional budget implementation in Papua. Thus it can be interpreted that the participation of the public has not played a role in the achievement of budget execution performance in Papua.

e. There is a positive and significant influence from the condition of political support from the legislature on the accountability of regional budget implementation in Papua Province. It means that the better legislative political support for the implementation of regional budgets in Papua, the higher performance of budget implementation, and vice versa.

f. There is a positive and very significant influence from the condition of accountability for the implementation of regional budgets on performance of regional budget execution in Papua. Thus, it can be said that the relationship between the accountability of regional budget execution and performance of regional budget execution in Papua is not only soling but also important on the role of accountability for the realization of an economical, efficient and effective implementation of regional budgets.

Based on the results, it can be concluded that there are several factors that can affect the performance of regio- nal budget execution, which is an effort to achieve a good government in Papua.

\section{Suggestion}

a. In order to improve the professionalism of regional instrument resources, leaders and subordinates need to be incorporated into education and training through a number of policies to make more effective result.

b. The work plan and budget of regional work unit formulated by each person in charge of SKPD should be based on the achieved work performance, budget procedures and techniques should be followed in an orderly and compliant manner.

c. The urgent handling and attention is needed to be carried out in cases that are in contact with the welfare of most of people with economically weak circles, such as handling dengue fever, improving the quality of early childhood education, and building school facilities and infrastructure whose budget management and implementation are classified as very weak in terms of value for money.

d. It is necessary to include the important indicators in future assesments of Budget performance includes outcome indicators, benefit indicators, and impact indicators.

\section{REFERENCES}

1. Amar S. (2012). Kajian Tentang Kinerja Anggaran Keuangan Daerah di Provinsi Sumatra Bara. J Ekon Pembang.

2. Hadjisaroso P. (2015). Tata Kelola Dan Kinerja Anggaran Belanja Daerah. J Ekon Dan Pembang Indones;22(3).

3. Loho S. (2017). AKuntansi Keuangan Pemerintah, Upaya Mewujutkan Kuntansi Keuangan dan Peningkatan Kinerja Pemerintah di Indonesia bagian Timur. Jakarta. 
4. Syahruddin, W.D T. (2012). The Role of The Regional Assembly in Achieving the Objective ot Decentralization and Regional Perspective in The Implementation of Decentralization. Padang.

5. Yani A. (2012). Hubungan Keuangan Antara Pemerintah Daerah dan Pemerintah Pusat di Indonesia. A Psicanal dos contos fadas Tradução Arlene Caetano.

6. Saragih (2013). Desentralisasi Fiskal dan Keuangan Daerah Dalam Otonomi. Jakarta: Penerbit Ghalia Indonesia.

7. Suparmoko M. (2014). Keuangan Negara dalam Teori dan Praktek. Yogyakarta: BPEE.

8. Mangkoesoebroto G. (2015). Ekonomi Publik. Yogyakarta: BPEE.

9. Halim A. (2017). Akuntansi dan pengendalian keuangan daerah. 3rd Editio. Yogyakarta: UPP AMP YKPN.

10. Lamba A, Allo PK \& Lamba RA. (2019). Effect of fiscal decentralization policy of regional economic imbalances towards economy growth in Eastern Indonesia. Int J Soc Sci Humanit. 3(2):112-27.

11. Nara (2019). Analisa Pengaruh Faktor-Faktor Kemampuan Sumberdaya Manusia Dalam Mempengaruhi Kinerja Aparatur Pemerintah Daerah Di Provinsi Papua. Unhas Makassar.

12. Mardiasmo, Makhfatih A. (2010). Perhitungan Potensi Pajak dan Ristribusi Daerah Kabupaten Magelang. Yogyakarta.

13. Riyanto, Ryan (2007). Membangun Profesionalisme Aparatur Dalam Mengembangkan Strategi Pelayanan Prima Melalui Peningkatan Kwalitas Sumber Aparatur. Jakarta: Rajawali Press.

14. Tintri D. (2002). Pengaruh Struktur dan Kultural Organisasional Terhadap Keefektifan Anggaran Partisipatif dalam Peningkatan Kinerja Manajerial. J Ekon dan Bisnis; 2(7).

Article received 25.02.2021

Reference a JournalArtic: Ramasoyan A.L., Arung Lamba', Kurniawan Patma \& Rudiawie Larasati. (2021). Analysis of the Factors that influence Performance in the Implementation of Regional Budgets as an Effort to Achieve a proper Government in Papua. Development of management and entrepreneurship methods on transport. 1 (74), 29-43. DOI 10.31375/2226-1915-2021-1-29-43. 